\title{
RANCANG BANGUN ALAT PENGUJIAN FOCUS FILM DISTANCE (FFD)
}

\section{DESIGN OF FOCUS FILM DISTANCE (FFD) TESTING TOOLS}

\author{
Andrey Nino Kurniawan \\ Health Polytechnics of Semarang-Indonesia \\ e-mail : andreynino_jtrr@poltekkes-smg.ac.id
}

\begin{abstract}
Background : Focus film distance (FFD) settings may affect the quality of radiograph, such as: density of the film, contrast, the intensity of x-ray radiation, detail and distortion of the image of the object, so that should be done appropriately. However, in practice, focus markers are often not given, lost or covered by accessories in x-ray tubes, so the technologist difficulties in determining the location of the focal point. It will make the technologist in the measurement of FFD done by measuring the approximate location of the focal point to the receptors. And yet there is a special tool that can be used to measure the accuracy of the settings of the FFD.
\end{abstract}

Methods : The research will focus on the design of FFD measurement tools using acrylic materials, copper wire and small iron balls. Research methods is experimental with trial and error design, tool architecture will be done some test functions, include: Test of acrillic material (radiograph image), copper wire alignment test, test of steady ball of iron ball, FFD measure test. Evaluation is done by comparing wire image measurement with mathematical calculation using magnification formula.

Results : The results of this research is the formation of FFD testing tool that is made has dimensions of $18 \mathrm{~cm} \mathrm{x} 10 \mathrm{~cm} \times 20 \mathrm{~cm}$ using acrillic material wich inside the part there is wire measuring $2 \mathrm{~cm}, 10 \mathrm{~cm}$, and $16 \mathrm{~cm}$ and two iron balls are mutually perpendicular. The function test of the device is obtained as follows: the test of acrilic material in the radiographic image has been able to distinguish the acrylic material with wire and iron ball so as not to interfere with the measurement of the leng th of the wire image; copper wire alignment test found that the position of each wire mounted on plate $\mathrm{A}$ is aligned and is $20 \mathrm{~cm}$ from the bottom of the tool; the steady iron ball deformity test on plate A and plate B is straight-forward

Conclusion: the FFD testing tool can already be used to determine the position of the focal point of the x-ray tube.

Keyword : focus film distance, the FFD testing tool

\section{PENDAHULUAN}

Focus-to-Film Distance(FFD) merupakan salah satu dari faktor primer yang digunakan dalam pemeriksaan radiografi. Focus-to-Film Distance (FFD) adalah jarak standar antara titik emisi sinar- $x$ yang ada di tabung sinar- $x$ (focal spot) dan image reseptor (Charlton, 2003).Pengaturan FFD dapat mempengaruhi kualitas radiograf, seperti : densitas film, kontras, intensitas radiasi sinar-x, detail dan distorsi citra objek ehingga pengaturan FFD harus dapat dilakukan secara tepat. Dan dalam hal pelaksanaan uji kesesuaian pesawat sinar-x yang diatur dalam Peraturan Pemerintah Republik Indonesia Nomor 29 Tahun 2008 tentang Perizinan Pemanfaatan Sumber Radiasi Pengion dan Bahan Nuklir dan Peraturan Kepala Badan Pengawas Tenaga Nuklir Nomor 9 Tahun 2011 tentang uji kesesuaian Pesawat Sinar-X Radiologi Diagnostik dan Intervensional bahwa dalam pengujian keandalan suatu pesawat dilakukan dengan cara pengukuran keluaran tabung sinar $\mathrm{x}$ dengan alat detektor pada jarak tertentu.

Pengukur FFD pada suatu model pesawat sinar- $\mathrm{x}$ sangatlah bermacam, baik secara elektronik maupun manual menggunakan meteran. Penggunaan pesawat sinar-x yang tidak hati-hati dapat dimungkinkan menyebabkan kerusakkan pada alat ukur FFD. Lokasi titik fokus pada tabung sinar-x biasanya dapat ditentukan dengan cara melihat tandadi rumah tabung sinar-x berupa titik lubang dan atau penanda sticker. Namun dalam praktiknya penanda fokus sering tidak diberi, hilang atau tertutup oleh asesoris pada tabung sinar-x, sehingga petugas kesulitan dalam menentukan lokasi dari titik fokus tersebut dan melakukan pengukuran FFD secara kirakira. Dan belum adanya suatu alat khusus yang dapat digunakan untuk mengukur ketepatan penentuan lokasi titik fokus dan pengaturan FFD.

Berdasarkan uraian diatas maka diperlukan suatu solusi yang dapat digunakan untuk memecahkan masalah tersebut adalah dengan merancang sebuah alat yang dapat digunakan untuk menentukan titik fokus dan FFD secara tepat.

\section{METODE}

Metode penelitian pada penelitian ini adalah rancang bangun suatu alat dengan metode trial and error. Penelitian ini dilakukan dengan langkah-langkah sebagai berikut :

\section{Perancangan Alat}

Perancangan alat dilakukan dengan terlebih dahulu membuat sketsa setiap bagian alat pengukur FFD yaitu kawat 
tembaga, plat acrillik dan letak dari bola besi kecil yang digunakan. Kawat tembaga yang digunakan adalah diameter kawat 0,5 mm yang ditanam pada plat acrilik, panjang kawat : 2 cm sebanyak 2 (dua) buah, $10 \mathrm{~cm}$ sebanyak 1 (satu) buah, dan $16 \mathrm{~cm}$ sebanyak 1 (satu) buah.

Plat acrilic. Plat acrilik yang digunakan berukuran $18 \mathrm{~cm}$ x 10 cm x 1,22 cm sebanyak 4 (empat) buah yang kemudian dirangkai menjadi sebuah kotak. Penempatan kawat tembaga dan bola besi pada plat acrilic diletakkan secara vertikal tegak lurus.

\section{Uji Fungsi}

Uji fungsi dilakukan untuk menilai fungsi-fungsi rancang bangun. Poin-poin uji fungsi alat meliputi:

\section{Uji bahan acrillic (citra radiograf)}

Uji bahan acrilik dengan cara mengeksposi dengan sinar-x dan pengaturan FFD sejauh $100 \mathrm{~cm}$, kemudian dinilai apakah bahan tersebut memiliki gambaran yang homogen dann tidak mengganggu citra kawat tembaga.

\section{Uji kesejajaran kawat tembaga}

Uji kesejajaran kawat tembaga dilakukan dengan cara mengukur kesejajaran letak kawat yang tertanam pada plat acrilik dengan menggunakan penggaris, yaitu : ujung-ujung kawat dan pertengahan kawat untuk tiap sisi plat acrilik

\section{Uji ketegaklurusan bola besi}

Uji ketegaklurusan bola besi dilakukan dengan cara mengukur kesejajaran letak kawat yang tertanam pada plat acrilik dengan menggunakan penggaris, yaitu tiap sisi plat acrilik.

\section{Uji alat pengukur FFD}

Uji alat pengukur FFD dengan cara mengeksposi dengan sinar-x dan pengaturan FFD sejauh $100 \mathrm{~cm}$, kemudian dinilai hasil citra kawat tembaga pada radiograf sudah sesuai dengan perhitungan yang telah dilakukan menggunakan rumus magnifikasi seperti pada table 1 .

Tabel 1. Hasil perhitungan panjang citra kawat menggunakan rumus magnifikasi.

\begin{tabular}{cccc}
\hline $\begin{array}{c}\text { PANJANG } \\
\text { KAWAT }\end{array}$ & FOD & FFD & $\begin{array}{c}\text { PANJANG } \\
\text { CITRA }\end{array}$ \\
\hline 5 & 80 & 100 & 6,25 \\
5 & 130 & 150 & 5,77 \\
5 & 160 & 180 & 5,63 \\
5 & 180 & 200 & 5,56 \\
10 & 80 & 100 & 12,50 \\
10 & 130 & 150 & 11,54 \\
10 & 160 & 180 & 11,25 \\
10 & 180 & 200 & 11,11 \\
16 & 80 & 100 & 20,00 \\
16 & 130 & 150 & 18,46 \\
16 & 160 & 180 & 18,00 \\
16 & 180 & 200 & 17,78 \\
\hline
\end{tabular}

\section{HASIL}

Hasil pada penelitian ini adalah terciptanya suatu alat pengujian FFD yang terdiri dari 4 sisi yaitu, 2 sisi penyangga dengan dimen si tinggi $21 \mathrm{~cm} \times 10 \mathrm{~cm}$, sisi atas berbentuk segi delapan dengan panjang $18 \mathrm{~cm} \times 10 \mathrm{~cm}$ dan terdapat beberapa ukuran kawat sebagai panduan ukur FFD yang diatur seperti pada gambar 1 .
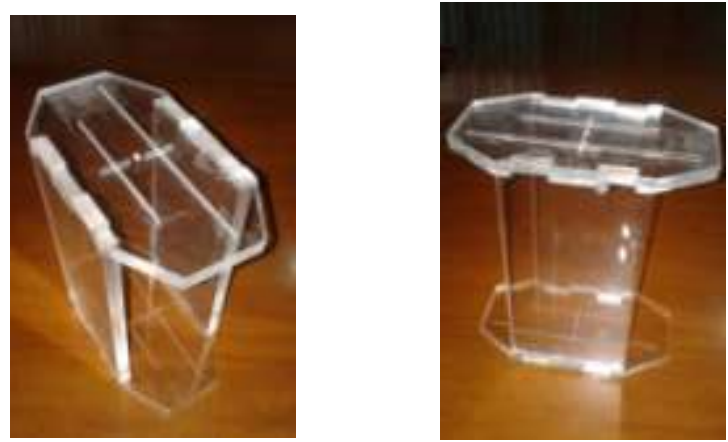

Gambar 1. Alat pengujian FFD

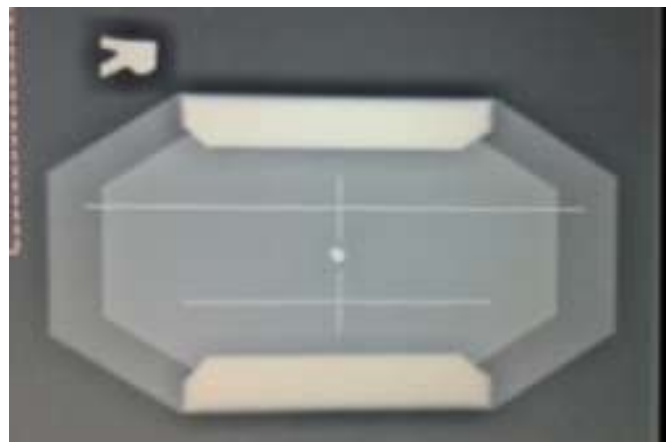

Gambar 2. Hasil uji fungsi alat pengujian FFD

Untuk uji fungsi alat tampak pada gambar 2 bahwa bahan acrilik, kawat dan bola besi sudah dapat dibedakan dengan jelas, sehingga pada hasil citra dapat dengan mudah dilakukan pengukuran dengan mengunakan tool pengukuran yang ada pada workstasion CR. Hasil percobaan pertama dengan menentukan suatu titik pada tabung sinar- $\mathrm{x}$ dan mengukur FFD sejauh $100 \mathrm{~cm}$ didapatkan hasil pengukuran sebagai berikut :

Tabel 2. Hasil percobaan pertama, perhitungan panjang citra kawat $10 \mathrm{~cm}$ menggunakan tool $\mathrm{CR}$ unit

\begin{tabular}{cccc}
\hline Posisi Alat & FOD & FFD & Panjang Citra Kawat \\
\hline Vertikal & $80 \mathrm{~cm}$ & $100 \mathrm{~cm}$ & $12,57 \mathrm{~cm}$ \\
Horisontal & $80 \mathrm{~cm}$ & $100 \mathrm{~cm}$ & $12,60 \mathrm{~cm}$ \\
\hline & & Rata-rata & $12,585 \mathrm{~cm}$ \\
\hline
\end{tabular}

Tabel 3. Hasil percobaan pertama, perhitungan panjang citra kawat $16 \mathrm{~cm}$ menggunakan tool $\mathrm{CR}$ unit

\begin{tabular}{cccc}
\hline Posisi Alat & FOD & FFD & Panjang Citra Kawat \\
\hline Vertikal & $80 \mathrm{~cm}$ & $100 \mathrm{~cm}$ & $20,11 \mathrm{~cm}$ \\
Horisontal & $80 \mathrm{~cm}$ & $100 \mathrm{~cm}$ & $20,11 \mathrm{~cm}$ \\
\hline & & Rata-rata & $20,11 \mathrm{~cm}$ \\
\hline
\end{tabular}


Hasil rata - rata pada kawat $10 \mathrm{~cm}$ dimasukkan dalam rumus magnisikasi didapatkan FFD sejauh 97,37 cm, sehingga masih terjadi kekurangan jarak sebesar 2, $63 \mathrm{~cm}$. Hasil rata rata pada kawat $16 \mathrm{~cm}$ dimasukkan dalam rumus magnisikasi didapatkan FFD sejauh 97,86 cm, sehingga masih terjadi kekurangan jarak sebesar 2,14 cm

Hasil percobaan kedua dengan menyesuaikan letak titik fokus pada tabung sinar-x berdasarkan hasil percobaan pertama dengan cara menambahkan jarak sejauh $2 \mathrm{~cm}$ dari posisi percobaan pertama sehingga didapatkan hasil sebagai berikut :

Tabel 4. Hasil percobaan pertama, perhitungan panjang citra kawat $10 \mathrm{~cm}$ menggunakan tool $\mathrm{CR}$ unit

\begin{tabular}{cccc} 
Posisi Alat & FOD & FFD & Panjang Citra Kawat \\
\hline Vertikal & $80 \mathrm{~cm}$ & $100 \mathrm{~cm}$ & $12,52 \mathrm{~cm}$ \\
Horisontal & $80 \mathrm{~cm}$ & $100 \mathrm{~cm}$ & $12,49 \mathrm{~cm}$ \\
\hline & & Rata-rata & $12,505 \mathrm{~cm}$ \\
\hline
\end{tabular}

Tabel 5. Hasil percobaan pertama, perhitungan panjang citra kawat $16 \mathrm{~cm}$ menggunakan tool $\mathrm{CR}$ unit

\begin{tabular}{cccc}
\hline Posisi Alat & FOD & FFD & Panjang Citra Kawat \\
Vertikal & $80 \mathrm{~cm}$ & $100 \mathrm{~cm}$ & $20,00 \mathrm{~cm}$ \\
Horisontal & $80 \mathrm{~cm}$ & $100 \mathrm{~cm}$ & $20,03 \mathrm{~cm}$ \\
\hline & & Rata-rata & $20,01 \mathrm{~cm}$ \\
\hline
\end{tabular}

Hasil rata - rata pada kawat $10 \mathrm{~cm}$ dimasukkan dalam rumus magnisikasi didapatkan FFD sejauh 99,84 cm, sehingga masih terjadi kekurangan jarak sebesar $0,16 \mathrm{~cm}$. Hasil rata rata pada kawat $16 \mathrm{~cm}$ dimasukkan dalam rumus magnisikasi didapatkan FFD sejauh $99,80 \mathrm{~cm}$, sehingga masih terjadi kekurangan jarak sebesar $0,20 \mathrm{~cm}$

\section{DISKUSI}

Untuk mengetahui uji fungsi alat pengujian FFD maka dilakukan penyinaran sinar-x pada alat tersebut.

\section{Uji bahan acrillic (citra radiograf)}

Uji bahan acrillic didapatkan hasil citra seperti pada gambar 2. Struktur plat A dan plat B tercitra saling superposisi, dimana plat A mengalami pembesaran bentuk dibandingkan dengan plat B yang berada pada dasar alat. Densitas plat A dab plat B dapat dibedakan satu sama lain, sedangkan plat pengangga tampak lebih opague karena secara geometris yang tegak akan memiliki ketebalan yang sama dengan tinggi alat. Densitas antara bahan acrillic, kawat tembaga, dan bola besi juga sudah dapat dibedakan secara jelas.

\section{Uji kesejajaran kawat tembaga}

Plat acrillic yang digunakan sebagai tempat dudukan kawat pada alat pengujian ini dilakukan pengukuran dan posisi paralel antara kawat 10 dan $16 \mathrm{~cm}$ menggunakan penggaris besi. Kesejajaran pengujian kawat tembaga dilakukan dengan cara melakukan penyinaran pada alat pengujian FFD yang diposisi secara beda yaitu vertikal dan horisontal. Pada percobaan pertama untuk kawat $10 \mathrm{~cm}$ didapatkan panjang citra kawat dengan selesih $0,03 \mathrm{~cm}$ dan untuk kawat $16 \mathrm{~cm}$ sama panjang, sedangkan pada percobaan kedua didapatkan untuk kawat $10 \mathrm{~cm}$ dan $16 \mathrm{~cm}$ didapatkan panjang citra kawat dengan selisih yang sama yaitu $0,03 \mathrm{~cm}$. sehingga dapat disimpulkan bahwa pemasangan posisi kawat tembaga pada alat pengujian FFD adalah sejajar dengan kaset. Uji ketegaklurusan bola besi

Ketegaklurusan dari kedua bola besi dilakukan dengan pembuatan potongan lembar acrillic secara presisi sebagai bahan pembentuk alat penguji, hal ini dapat dilihat pada gambar 6 dimana plat acrillic pembentuk alat penguji tidak terlalu banyak mengalami distorsi atau kelainan geometri bentuk. Pada hasil citra pada gambar 2 tampak bahwa kedua bola besi saling superposisi, hal ini menandakan bahwa posisi keduanya sudah saling tegak lurus.

\section{Uji alat pengujian FFD}

Prinsip kerja alat ini adalah berdasarkan dengan pembesaran suatu benda akibat adanya jarak antara reseptor citra, objek dan sumber sinar-x seperti pada rumus magnifikasi (1). Secara harafiah fokus merupakan titik dimana terjadinya sinar-x atau tumbukkan elektron pada anoda yang terjadi pada tabung insersi, dan pada umumnya diberi tanda pada sisi rumah tabung yang dapat dilihat.

Uji alat ini dilakukan dengan dilakukan penyinaran pada alat pengujian FFD kemudian hasil citra kawat dilakukan pengukuran dengan mengunakan tool pengukuran yang ada pada workstasion CR seperti pada gambar 3 .

Hasil citra kawat yang telah diukur dimasukkan kedalam rumus magnifikasi juga dapat dihitung dengan rumus sebagai berikut (Bushong, 2001):

$$
\mathrm{M}=\frac{\text { ukuran pada radiograf }}{\text { ukuran sebenarnya }}=\frac{\text { FFD }}{\text { FOD }}
$$

Ukuran sebenarnya $=$ ukuran pada radiograf $\times\left(\frac{\mathrm{FFD}}{\mathrm{FOD}}\right)$
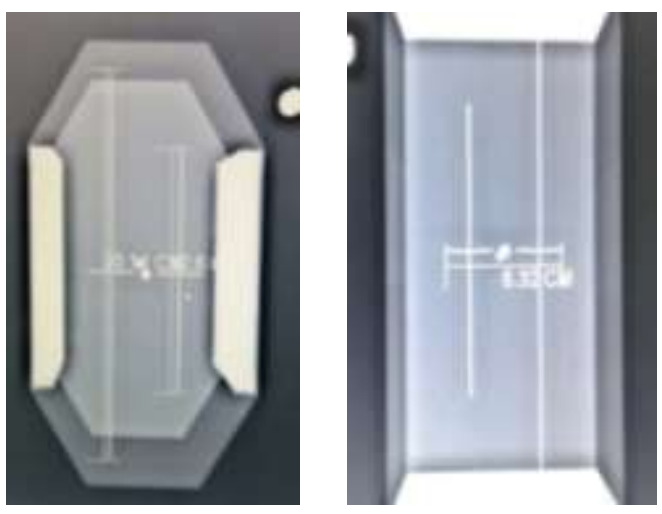

Gambar 3. Pengukuran citra kawat

Percobaan pertama pada panjang kawat $10 \mathrm{~cm}$ didapatkan citra kawat sepanjang 12,585 $\mathrm{cm}$, apabila dihitung maka akan didapatkan jarak FFD sebesar 97,37 cm dngan selisih jarak sebesar $2,63 \mathrm{~cm}$. Untuk kawat $16 \mathrm{~cm}$ didapatkan 
citra kawat 20,11 cm, apabila dihitung maka akan didapatkan jarak FFD sebesar 97,86 cm dngan selisih jarak sebesar 2,14 $\mathrm{cm}$. Sehingga pada percobaan pertama ini didapatkan rata-rata FFD yang didapatkan adalah 97,62 $\mathrm{cm}$ dan kurang 2,38 cm untuk pengaturan FFD sejauh $100 \mathrm{~cm}$.

Percobaan kedua dilakukan dengan cara menambah jarak sejauh $2 \mathrm{~cm}$ daripada posisi semula pada percobaan pertama, penambahan jarak ini masih dalam batasan wajar artinya masih pada area tabung sinar-x. Percobaan kedua ini didapatkan hasil panjang kawat $10 \mathrm{~cm}$ didapatkan citra kawat sepanjang $12,51 \mathrm{~cm}$, apabila dihitung maka akan didapatkan jarak FFD sebesar 99,84 cm dngan selisih jarak sebesar 0,16 $\mathrm{cm}$. Untuk kawat $16 \mathrm{~cm}$ didapatkan citra kawat 20,01 cm, apabila dihitung maka akan didapatkan jarak FFD sebesar $99,80 \mathrm{~cm}$ dngan selisih jarak sebesar $0,20 \mathrm{~cm}$. Sehingga pada percobaan kedua didapatkan rata-rata FFD yang didapatkan adalah 99,82 $\mathrm{cm}$ dan kurang 0,18 $\mathrm{cm}$ untuk pengaturan FFD sejauh $100 \mathrm{~cm}$.

Berdasarkan kedua percobaan diatas maka dapat disimpulkan bahwa alat pengujian FFD ini dapat berfungsi untuk menentukan titik fokus pada tabung sinar-x. Namun dalam penelitian ini pengujian alat ini baru dilakukan pada satu jenis pesawat sinar-x sehingga masih perlu dilakukan uji coba pengujian pada pesawat sinar-x lainnya.

\section{SIMPULAN}

Alat pengujian FFD yang dibuat memiliki dimensi 18 $\mathrm{cm}$ x $10 \mathrm{~cm}$ x $20 \mathrm{~cm}$ menggunakan bahan acrillik yang didalam bagiannya terdapat kawat berukuran $2 \mathrm{~cm}, 10 \mathrm{~cm}$, dan $16 \mathrm{~cm}$ serta dua buah bola besi yang saling tegak lurus

Hasil uji fungsi dari rancangan alat pengujian FFD yang dibuat sudah dapat digunakaan untuk menentukan posisi titik fokus pada tabung sinar-x sesungguhnya dan begitu juga jarak dari FFD.

\section{DAFTAR PUSTAKA}

Bushong, Steward C. 2001. Radiologic Science for Technologists Physics, Biology, and Protection Seventh Edition. CV. Mosby Company : USA

Carlton, Adler. 2003. Radiologic Sciences and Patient Care. 3th Editions. USA.

Carlton, Richard R. 2001. Prinsiple of Radiographic Imaging an Art and A Science. 3rd Editions. Thomson Learning : New York.

Chesney, D. N and Chesney O. Muriel. 1989. Radiographic Imaging. 5th Editions. Blackwell Scientific Publication : Oxford London

Currie, Thomas S. 1984. Introdustion to the physics of Diagnostic Radiology. Lea and Febiger : Phyladelphia.

Jenskins, David. 1980. Radiographic Photography and Imaging Processes. An Aspen Publication : Maryland.

Robert, Derrick P, and Nigel L. Smith. 1980. Radiographic Imaging.Churchill livingstone : USA. 